\title{
RESEARCH ARTICLE \\ A COMPARATIVE STUDY OF CULINARY PRACTICES OF HOMEGROWN COOKS AND CHEFS IN CONTEMPORARY PHILIPPINE CUISINE OF HEIRLOOM RECIPES OF CALABARZON
}

\author{
Ninevetch Grace O. Marco, DBM-HM \\ Laguna State Polytechnic University - San Pablo City Campus \\ *Corresponding Author Email: go7172@yahoo.com
}

This is an open access article distributed under the Creative Commons Attribution License, which permits unrestricted use, distribution, and reproduction in any medium, provided the original work is properly cited.

\section{ARTICLE DETAILS}

\section{Article History:}

Received 01 August 2019 Accepted 02 October 2019 Available online 10 October 2019

\begin{abstract}
This study aimed to analyse the heirloom recipes of CALABARZON from the assessment of the homegrown cooks who are continuously practicing traditional methods and chefs who are currently working in restaurants. Guided by a conceptual framework, the study evaluated through descriptive method in utilizing to the limitations of single design addressing a question and theoretical perspective at different levels of the heirloom .Field survey identified the gaps supported by interviews conducted to select homegrown cooks and chefs for a more in-depth analysis to the data gathered. Based from the findings of the study, the assessment of chefs and homegrown cooks are significantly different from each other. In comparing the results, the chefs have different perspectives from the homegrown cooks regarding heir-loom recipes that perhaps in connection to their experience and education. Results also highlighted some important considerations in preservations actions proposing as to how heirloom recipes can be integrated to the Contemporary Philippine Cuisine.
\end{abstract}

\section{KEYWORDS}

Heirloom recipes, Culinary practices, homegrown cooks, chefs, Contemporary Philippine cuisine.

\section{INTRODUCTION}

Many people think about food as a sole sustenance, a source of nutrients and energy to live. Though food is a necessity, however, it is not just a pure biological need. In fact, food can reveal a great deal about culture. Hence, the researcher intendedly expressed interest towards the study as the researcher is also inclined in cooking particularly with native Filipino dishes.

The food choices that we make and the development of our behaviour and habits concerning food are influenced by many interacting factors, including availability, income, culture, concerns about health, social values, religion, and even genetics. Most persons and in ordinary circumstances, foods must be palatable or have appetite appeal if they are to be eaten. Food for today Culture is a set of customs traditions, and beliefs, shared by a large of people [1,2].

However, of particular interest to this study is the subject of food and its relevance to culture. Early anthropologists studied food be-cause of its central role in many cultures. Heirloom dishes are essentially considered of special value especially to local culture since these are parts of a locality's heritage that is being handed down from generations to generations.

\section{OBJECTIVES OF THE STUDY}

This research aims to focused on the analysis of the heirloom recipes in Region IV-A and their culinary traditions as practiced by homegrown cooks and professional chefs. The results of this study are expected to primarily benefit the culinary and tourism sector since this research will propose a paradigm of culinary heirloom recipes in Region IV-A which may be undertaken in order to pre-serve and integrate these heirloom recipes to the contemporary Philippine cuisine.

\section{CONCEPTUAL FRAMEWORK}

The conceptual framework of the study shows cause and effect of the culinary traditions of homegrown cooks and professional chefs in classifying Heirloom recipes. It also includes heirloom recipes of CALABARZON according to popularity index as well as their cultural and historical significance in terms of food heritage and authenticity.

A fishbone diagram, also called a cause and effect diagram or Ishikawa diagram, was used as a tool for categorizing the potential causes of a problem in order to identify its root causes.

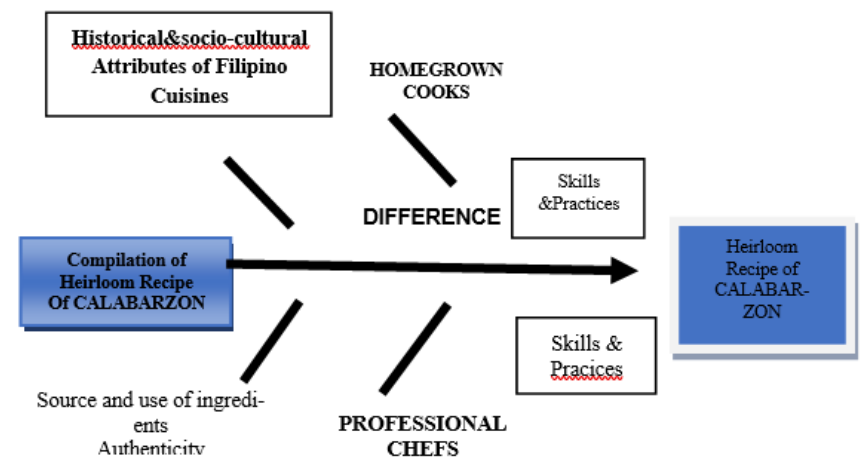

Culinary practices

Figure 1: Research Paradigm

\section{STATEMENT OF THE PROBLEM}

The study aimed to classify the heirloom recipes in Region IV-A and examined its culinary traditions as practiced by the homegrown cooks, who were largely self-taught, and practice in family or heritage settings, and the professional chefs or cooks, who were professionally trained and currently working in commercial settings such as restaurants, catering firms and hotel kitchens in the different provinces in the region. 
Further, it sought to answer the following questions:

1. What are the heirloom recipes in Region IV-A which defined historical and socio-cultural attributes and can be considered as traditional cuisines of Filipinos?

2. What are the culinary practices in preparing heirloom recipes by the homegrown cooks and professional chefs in Region IV-A in terms of:

2.1 Source and use of ingredients

2.2 Cooking methods and techniques

2.3 Authenticity and

2.4 Skills required

3. Is there a significant difference between the ratings of the homegrown cooks and professional chefs on the culinary practices of the heirloom recipes in Region IV-A?

4. What are the contributions of the heirloom recipes from Region IV-A to the Filipino Heritage Cuisines?

5. Based from the findings of the study, how can a paradigm of culinary heirloom recipes in Region IV-A be proposed to preserve these recipes and integrate these in the contemporary Philippine cuisine?

\section{LITERATURE REVIEW}

The globalization theory of world culture, which encompasses the homogeneity versus the heterogeneity dispute and the significance of the local as an essential ingredient of the overall globalization process, theorizes how globalization is actually presenting people with diverse experiences despite the con-vergence in tastes [3]. The emphases on eating the cuisine where it is native rather than the processed food via franchising worldwide, the growing resurgence of the local through resistance movements like the Slow Cities and Slow Food which offer the tourists a taste of 'real' local food, are all examples of the dialectical relationship be-tween globalization and localization. The globalization theory is hence employed in this paper to analyse the role of macrostructural forces in explaining food tourism. Cultural Capital Theory refers to the collection of symbolic elements such as skill tastes, posture, clothing, mannerism, material belongings, credentials, etc [4]. However, some researcher points out the cultural capital valued over others and can help or hinder one's social mobility just as much as income or wealth [4]. According to a study, cultural capital comes in three forms embodied objectified, and institutionalized [5]

One's accent or dialect is an example of embodied cultural to credential and qualification such as degrees or titles that symbolize cultural competence and authority. Also, the theory underestimates the role of social network diversity and other complex modern social structures that contribute to cultural capital [3]. This makes the Cultural Capital Theory a theory of reproduction of status. Stated that "We are moving towards the society without fixed status groups in which the adoptions of styles of life, which be predetermined to specific groups, have been suppressed" provides an ap-propriate criticism of the Cultural Capital Theory [3]. With this criticism in mind, recent studies on Cultural Capital Theory have looked into the stratification of consumption and differentiation in tastes as a product of lifetime choices.

This theory revolves around the differ-ential ability to control the definition of what is "good to eat". This theory Taste is also anatomically determined [6]. Scientist categorizes people as "tasters" or "non-taster." Which category you fall into depends on how many taste buds you have on your tongue- an inherited trait. Non-tasters with few taste buds don't taste bitter foods like grapefruit and broccoli very in-tensely." [4]. As stated above, the 'cultural omnivore' perspective of cultural capital views the breadth of knowledge about various cultural forms and practices as cultural capital. With respect on food, cultural capital may reside in knowledge about gourmet foods, exotic flavors, foods that are acquired tastes, and familiarity with advanced preparation techniques.

According to Newman (2013, Book of 7000 Islands), the word fiesta is a colonial legacy. In Spanish, it means a religious celebration or a special event. While the Philippines embraced the term along with many Spanish customs, an indigenous tradition of celebration was long in place.

\section{MATERIALS AND METHODS}

\subsection{Research Design}

The researcher used descriptive method in utilizing to the limitations of a single design. It involves proper explanation in data interpretation, exploring a phenomenon, developing and testing a new instrument, serving as a theoretical perspective, complementing the strengths of a single design, overcoming the weaknesses of a single design, addressing a question and theoretical perspective at different levels.

\subsection{Population and Sample}

The study involved the participation of 150 selected homegrown cooks identified from locally known families and 100 professional chefs who are connected to restaurants, catering firms or local hotels in selected cities in the CALABARZON Region. The researcher sought assistance from the local government in the selected cities in order to identify the homegrown cooks from local prominent families as well as the professional chefs or cooks from local restaurants, catering firms or local hotels. The researcher used purposive sampling in order to arrive at the number of respondents involved in this study.

\subsection{Data Gathering Procedure}

To initiate the data gathering, the researcher identified and selected the respondents from the locally prominent families as well as the commercial foodservice establishments in the selected cities in CALABARZON Region. To the identified respondents, a letter requesting their availability for the interview was given, considering the day, time and place of the interview. The researcher recorded the activities that transpired in the interview sessions and then interpret-ed and analyzed the results to answer the subproblems of this study

\subsection{Data Gathering Instrument}

The researcher made use of survey questionnaire guided by the characteristics of a good recipe and interview as the main tools in data gathering [6]. In preparing the items to be included in the survey questionnaire, the researcher referred to related studies and other published references as basis.

The first part of the questionnaire included questions aiming to generate information about the profile of respondents. The second part of the survey questionnaire focused on questions seeking to obtain perceptions of respondents on the quality of the heirloom recipes in the selected cities in CALABARZON in terms of ingredients, sensory properties, preparations and cooking techniques, serving and presentation. In administering the questionnaires to target respondents, a letter was given to ask for their consent and participation in the survey. In terms of scoring of responses, the following scale shall be used:

\begin{tabular}{|c|c|c|}
\hline Weight & Interpretation & Scale \\
\hline 5 & Strongly Agree & $4.20-5.00$ \\
\hline 4 & Agree & $3.40-4.19$ \\
\hline 3 & Moderately Agree & $2.60-3.39$ \\
\hline 2 & Disagree & $1.80-2.59$ \\
\hline 1 & Strongly Disagree & $1.00-1.79$ \\
\hline
\end{tabular}

\subsection{Statistical Tools}

The researcher analyzed the statistical results in two steps. First descriptive correlational statistics, such as percentages, mean scores and standard deviation were used to analyze demographics, heir-loom recipes characteristics assessments of both set of respondents [7-11]. The researcher provided a $t$-statistical analysis to bridge the gap among the variables from the two set of respondents.

\section{RESULT AND DISCUSSION}

7.1 Profile of the respondents

\subsubsection{Distribution of the respondents}

Table 1: Distribution of the Respondents

\begin{tabular}{|c|c|c|}
\hline Respondents & F & \% \\
\hline Homegrown cooks & 150 & $60 \%$ \\
\hline Professional Cooks & 100 & $40 \%$ \\
\hline Total & $\mathbf{2 5 0}$ & $\mathbf{1 0 0 \%}$ \\
\hline
\end{tabular}

\subsubsection{Profile of the Respondents}

As shown in Table 1 based on its distribution were $60 \%$ of the respondents were Homegrown cooks of selected towns in CALA-BARZON and $40 \%$ were Professional Chefs of selected towns of CALABARZON. 
Table 2: Profile of the Respondents

\begin{tabular}{|c|c|c|c|c|}
\hline AGE & $\begin{array}{c}\text { PROFESSIONAL } \\
\text { CHEF }\end{array}$ & $\begin{array}{c}\text { HOMEGROWN } \\
\text { COOKS }\end{array}$ & F & \% \\
\hline $21-30$ & 23 & 55 & 78 & $31 \%$ \\
\hline $31-40$ & 39 & 36 & 75 & $30 \%$ \\
\hline $41-50$ & 29 & 24 & 53 & $21 \%$ \\
\hline $51-60$ & 6 & 28 & 34 & $13 \%$ \\
\hline $\begin{array}{c}60 \text { and } \\
\text { above }\end{array}$ & 3 & 7 & 10 & $4 \%$ \\
\hline TOTAL & $\mathbf{1 0 0}$ & $\mathbf{1 5 0}$ & $\mathbf{2 5 0}$ & $\mathbf{1 0 0} \%$ \\
\hline
\end{tabular}

\subsubsection{Table 3 Profile of the respondents based on gender}

Table 3: Profile of the Respondents based on Gender

\begin{tabular}{|c|c|c|c|c|}
\hline GENDER & $\begin{array}{c}\text { PROFESSIONAL } \\
\text { CHEF }\end{array}$ & $\begin{array}{c}\text { HOMEGROWN } \\
\text { COOKS }\end{array}$ & F & \% \\
\hline MALE & 78 & 83 & 161 & $64 \%$ \\
\hline FEMALE & 22 & 67 & 89 & $36 \%$ \\
\hline TOTAL & $\mathbf{1 0 0}$ & $\mathbf{1 5 0}$ & $\mathbf{2 5 0}$ & $\mathbf{1 0 0}$ \\
\hline
\end{tabular}

As shown on Table 3 based on gender were in majority of the respondents were male $64 \%$ and female respondents were composed of $36 \%$ of the respondents.

\subsection{Heirloom Recipes in Region IV-A}

Table 4 are the preferred heirloom recipes of the respondents based on their expertise and/or place of residence.

Table 4: Heirloom Recipes in Region IV-A

\begin{tabular}{|c|c|c|c|}
\hline Location & $\begin{array}{c}\text { HEIRLOOM } \\
\text { RECIPE }\end{array}$ & FREQUENCY & PERCENTAGE \\
\hline $\begin{array}{c}\text { Quezon/ } \\
\text { Cavite }\end{array}$ & Tamales & $\mathbf{2 3}$ & $\mathbf{9 . 4 7 \%}$ \\
\hline Cavite & Seafoods Paella & $\mathbf{1 8}$ & $\mathbf{7 . 3 7 \%}$ \\
\hline $\begin{array}{c}\text { Laguna/ } \\
\text { Quezon }\end{array}$ & Kulawo & $\mathbf{1 2}$ & $\mathbf{5 . 2 6} \%$ \\
\hline Laguna & Kinulob na Itik & $\mathbf{3 1}$ & $\mathbf{1 2 . 6 3 \%}$ \\
\hline Batangas & Bulalo & $\mathbf{3 0}$ & $\mathbf{1 2 . 6 3 \%}$ \\
\hline Batangas & Adobo sa dilaw & $\mathbf{1 5}$ & $\mathbf{6 . 3 2} \%$ \\
\hline Rizal & BINARUTAK & $\mathbf{1 0}$ & $\mathbf{4 . 2 1 \%}$ \\
\hline Laguna & Bukopie & $\mathbf{2 0}$ & $\mathbf{8 . 4 2} \%$ \\
\hline Quezon & Pancithabhab & $\mathbf{3 8}$ & $\mathbf{1 5 . 7 9 \%}$ \\
\hline Quezon & Lucban Longanisa & $\mathbf{5 3}$ & $\mathbf{1 7 . 8 9 \%}$ \\
\hline & TOTAL & $\mathbf{2 5 0}$ & $\mathbf{1 0 0 . 0 0 \%}$ \\
\hline
\end{tabular}

As shown on Table 4, Longanisa Lucban is the most preferred heirloom recipe at $\operatorname{rank} 1(\mathrm{f}=17 ; \mathrm{P}=17.89 \%)$, rank 2 is $\mathrm{Pancit}$ Ha-bhab $(\mathrm{f}=15 ; \mathrm{P}=$ $15.79 \%$ ) then Kinulob na itik $(\mathrm{f}=12 ; \mathrm{P}=12.63 \%)$ and Bulalo $(\mathrm{f}=12 ; \mathrm{P}=$ $12.63 \%$ ) both at rank 3 . These heirloom recipes comprise the three most frequently cooked by the respond-ents. Rank 4 is the Tamales ( $\mathrm{f}=9$; $\mathrm{P}=9.47 \%)$ followed by Buko-pie( $\mathrm{f}=8 ; \mathrm{P}=8.42 \%)$ at rank 5 then Seafood Paella $(\mathrm{f}=7 ; \mathrm{P}=7.37)$ at rank 6 . Meanwhile, the considered three least preferred heirloom recipes with minimal difference from the latter's three recipe results are; Adobo Sadilao $(\mathrm{f}=6.32 \%)$ at rank 7, Kulawo $(=5 ; \mathrm{P}=$ $5.26 \%$ ) rank 8 and Binarutak at rank 9 respectively.

7.3 Frequency and percentage distribution of respondents according to heirloom recipe

Table 5: Frequency and percentage distribution of the respondents according to heirloom recipe

\begin{tabular}{|c|c|c|c|}
\hline $\begin{array}{l}\text { HEIRLOOM } \\
\text { RECIPE }\end{array}$ & FREQUENCY & PERCENTAGE & RANK \\
\hline Tamales & 23 & $9.47 \%$ & 4 \\
\hline Seafood paella & 18 & $7.37 \%$ & 6 \\
\hline Kulawo & 12 & $5.26 \%$ & 8 \\
\hline $\begin{array}{c}\text { Longanisang } \\
\text { Lucban }\end{array}$ & 53 & $17.89 \%$ & 1 \\
\hline Bulalo & 30 & $12.63 \%$ & 3 \\
\hline Adobo sadilaw & 15 & $6.32 \%$ & 7 \\
\hline BINARUTAK & 10 & $4.21 \%$ & 9 \\
\hline Bukopie & 20 & $8.42 \%$ & 5 \\
\hline Pancithabhab & 38 & $15.79 \%$ & 2 \\
\hline Kinulob na Itik & 31 & $12.63 \%$ & 3 \\
\hline TOTAL & 250 & $100.00 \%$ & \\
\hline
\end{tabular}

As presented in Table 5, the profile of each heirloom recipe with its distinct characteristics and origin is described. It can be noticed that each heirloom dish represents each province that belongs to Region IV-A or CALABARZON and most of these dishes have their origins traced back or associated with the provinces.

7.4 Culinary Practices in preparing Heirloom Recipes as by the Homegrown cooks and Professional chefs

Table 6: Culinary Practices in Preparing Heirloom Recipes as by the Homegrown Cooks and Professional Chefs

\begin{tabular}{|c|c|c|}
\hline \multirow[t]{2}{*}{ Location } & \multicolumn{2}{|c|}{ Culinary Practices } \\
\hline & Homegrown Cooks & Professional Chef \\
\hline Cavite & $\begin{array}{l}\text { Seafoods are the main } \\
\text { ingredients to their } \\
\text { dishes } \\
\text { Traditionally they used } \\
\text { atchuete (anato) seeds as } \\
\text { food coloring } \\
\text { Used banana leaves in } \\
\text { wrapping foods such as } \\
\text { their famous Tamales. } \\
\text { Used wood and charcoal } \\
\text { in cooking such as } \\
\text { brasing, roasting and } \\
\text { boiling. }\end{array}$ & $\begin{array}{l}\text { Seafoods are their main } \\
\text { ingredients in their } \\
\text { dishes as the province } \\
\text { has abundance } \\
\text { resources. } \\
\text { As professional Chef they } \\
\text { practiced fusion cooking } \\
\text { methods as they were } \\
\text { exposed to the } \\
\text { traditional and western } \\
\text { type of cooking. } \\
\text { As mentioned in the } \\
\text { interview they also adapt } \\
\text { the old way of } \\
\text { preserving food but they } \\
\text { mixed it with new trends } \\
\text { like kitchen twine, used } \\
\text { of aluminum foil in } \\
\text { wrapping. } \\
\text { Used food processor }\end{array}$ \\
\hline Laguna & $\begin{array}{l}\text { Widely used of coconut } \\
\text { as their main } \\
\text { ingredients. } \\
\text { They used the traditional } \\
\text { way of extracting of } \\
\text { coconut milk by using } \\
\text { hands. } \\
\text { They even used "tungko" } \\
\text { as their stove for cooking } \\
\text { specially if it requires } \\
\text { long hours of cooking. } \\
\text { They practiced smoking } \\
\text { of grated coconut to } \\
\text { obtain distinctive burnt } \\
\text { taste of their dishes. }\end{array}$ & $\begin{array}{l}\text { They used canned } \\
\text { coconut milk. } \\
\text { They used food } \\
\text { processor in extracting } \\
\text { coconut milk. } \\
\text { They substitute some } \\
\text { local ingredients to } \\
\text { instant ingredients. } \\
\text { They used heavy duty } \\
\text { cooking equipment. } \\
\text { They used electric } \\
\text { powered cooking } \\
\text { equipment. }\end{array}$ \\
\hline Batangas & $\begin{array}{l}\text { They still used claypot in } \\
\text { cooking their dishes } \\
\text { particularly "sinaing na } \\
\text { tulingan" } \\
\text { Used banana leaves in } \\
\text { wrapping food such as } \\
\text { fish, rice. } \\
\text { Used charcoal, wood for } \\
\text { hours of boiling like their } \\
\text { famous "bulalo". }\end{array}$ & $\begin{array}{l}\text { They used pressure } \\
\text { cooker, slow cooker. } \\
\text { They used foil, cling } \\
\text { wrap in wrapping foods. } \\
\text { Used electric powered } \\
\text { stove. }\end{array}$ \\
\hline Rizal & $\begin{array}{l}\text { Still practiced } \\
\text { preparing/ cooking } \\
\text { unique dishes such as } \\
\text { rice field frogs, coconut } \\
\text { worm (uok), adobong } \\
\text { camaro and soup no.5 } \\
\text { ( bat and ball soup) } \\
\text { Fermented rice with } \\
\text { shrimp or fish as their } \\
\text { dipping sauce for grilled, } \\
\text { roasted or fried dish. } \\
\text { (balawbalaw) }\end{array}$ & $\begin{array}{l}\text { Introduced western way } \\
\text { of fermentation. } \\
\text { Do not practice cooking } \\
\text { exotic dishes. } \\
\text { They substitute some } \\
\text { local ingredients to } \\
\text { instant ingredients. }\end{array}$ \\
\hline Quezon & $\begin{array}{l}\text { They used hog casing } \\
\text { (intestine) in preparing } \\
\text { local sausage } \\
\text { Banana and coconut } \\
\text { leaves as food wrap. } \\
\text { Coconut shell as their } \\
\text { food container and } \\
\text { cooking utensils. }\end{array}$ & $\begin{array}{l}\text { They used hog casing } \\
\text { (intestine) in preparing } \\
\text { local sausage } \\
\text { Used banana leaves also } \\
\text { but they also used foil } \\
\text { and plastic wrap in } \\
\text { wrapping foods. } \\
\text { Used pressured cooker. }\end{array}$ \\
\hline
\end{tabular}




\begin{tabular}{l|l}
$\begin{array}{l}\text { Palayok were frequently } \\
\text { used as their cook ware. }\end{array}$ & $\begin{array}{l}\text { In grilling they used } \\
\text { electric griller. } \\
\text { Coconut milk "gata" for } \\
\text { viand and dessert. }\end{array}$ \\
$\begin{array}{l}\text { Sometimes they used } \\
\text { canned coconut milk. }\end{array}$
\end{tabular}

Shown on Table 6, the current Heirloom recipes culinary practices by the Homegrown cooks and Chefs based on articles and respondents interview.

\subsection{Weighted mean and rank of chefs as to ingredients}

Table 7: Weighted mean and rank of chefs as to ingredients

\begin{tabular}{|l|c|c|c|}
\hline \multicolumn{1}{|c|}{ Indicators } & $\begin{array}{c}\text { Weighted } \\
\text { Mean }\end{array}$ & $\begin{array}{c}\text { Verbal } \\
\text { Interpretation }\end{array}$ & Rank \\
\hline $\begin{array}{l}\text { 1. Traditional } \\
\text { ingredients are used } \\
\text { in the heirloom } \\
\text { recipes. }\end{array}$ & $\mathbf{3 . 4 5}$ & Agree & 3 \\
\hline $\begin{array}{l}\text { 2. The ingredients } \\
\text { used in the recipes } \\
\text { are of good quality. }\end{array}$ & 4.25 & Strongly Agree & 2 \\
\hline $\begin{array}{l}\text { 3. The ingredients } \\
\text { can be easily found in } \\
\text { the local market. }\end{array}$ & 4.65 & Strongly Agree & 1 \\
\hline Composite Mean & 4.12 & Agree & \\
\hline
\end{tabular}

Shown on Table 7 are the three indicators for heirloom recipes cooking methods and techniques and it was revealed that one indicator was rated as "agree" and this was the traditional cooking wares are used in preparing the recipes with a mean rating of 4.15. The two indicators were said to "strongly agree" and these were the recipes are prepared using traditional cooking methods $(w m=4.68)$ and the recipes are prepared in traditional texture and consistency $(\mathrm{wm}=4.35)$. The overall mean rating for heirloom recipes preparations and cooking techniques is 4.39 and this is interpreted as "strongly agree" [12-15]. It is evident that the respondents believe that tech-niques used in preparing a dish can affect what the dish is like as much if not more than the ingredients themselves [7]

\section{CONCLUSION}

1. Longanisang Lucban is the most preferred heirloom recipe of the two set of respondents at rank 1 which originated in Quezon.

2. The considered three least preferred heirloom recipes with minimal difference were; Adobo Sadilao, Kulawo, and Binarutak which were originated from Batangas, Laguna and Rizal respectively.

3. The heirloom recipes as to ingredients were rated "agree" by the chefs. On the other hand, it is evident that the homegrown cooks "strongly agree" that heirloom

4. recipes possess quality characteristics as to ingredients.

5. According to the chefs, they "strongly agree" that the sensory properties of heirloom recipes are of good quality while the homegrown cooks "strongly agree" that heir-loom recipes are totally appetizing with an overall mean rating of 4.66 which imply very acceptable authentic properties.

6. The chefs overall mean rating for heirloom recipes preparations and cooking techniques is interpreted as "strongly agree" while homegrown cooks "strongly agree" that the heirloom recipes are well prepared and with appropriate cooking techniques.

7. The chefs "agree" that the heirloom recipes have good serving and presentation. Meanwhile, the homegrown cooks "strongly agree" that traditional recipes are proper-ly served and attractively presented.

8. The results from the data caused for the rejection of the null hypothesis which means that there are indeed significant differences on the assessment of chefs and home-grown cooks in the characteristics of heirloom recipes.

\section{ACKNOWLEDGEMENT}

The researcher is indebted to many individuals that contributed to the completion of this humble research study. Therefore, it is with great gratitude, appreciation and modesty that acknowledgements be made to those persons who accompanied the researcher throughout her journey and to others who came alongside. Some of them may not be mentioned inadvertently but still sincerest gratitude is ex-pressed to all of them.

Deepest appreciation to the following:

- First and foremost, she would like to give her thanks to the Al-mighty God for giving her the strength and courage to carry out this work.

- To the LSPU-SPCC family, school key officials, colleagues, students and friends for all the moral support and challenges pooled with the researcher which made her tougher and a better individual;

- To her CHMT LSPU-SPCC family for their support and invigorating words to motivate her to finish what she has started;

- To Dr. Portia R. Marasigan, Ms. Elaine Apat for the immortal friendship that they intertwined together to make this endeavor possible;

\section{REFERENCES}

[1] Bennion, Marion. 2009. by Introductory Foods.

[2] Besa, A., Dorotan, R. 2006. The Philippines, co-authored Memories of Philippine Kitchens

[3] Fenix, M. 2005. Ilustrado Banquets Manila Standard Today Newspaper

[4] Bourdieu, P. 1984. Distinction: A Social Critique of the Judgment of the Taste. London: Routledge \& Kegan Paul

[5] Europe Word Administration. 2008 http://www.europeword.com/blog/europe/european-cuisine/

[6] Civitello, J. 2009. Mastering the Art of French Cooking. Fortieth Anniversary Hardcover Edition. October 16, 2001

[7] Avieli, N., Cohan, E. 2004. Food in Tourism: Attraction and impediment Annals.

[8] Adema, J. 2000. History of Philippine Cuisine www.foodtimeline.org http://sites.duke.edu/pwendy/food-culture/ Migration, Food, and Culture. A Cambodian Experience.

[9] Bauer Media Pty Limited. 2012. Hong Kong's Disapearin Dishes [Online]. Available: http://www.gourmettraveller.com.au/travel/travelguides/2012/11/the-disappearing-dishes-of-hong-kong/

[10] Calmorin, L., Calmorin, M. 1998. Research Designs Methods of Thesis Writing Contel, M., et al. (2010) When Serving Good Food is Matter of Honor Customer-driven definition of tradition food products and innovation in traditional foods. Food Quality and Preference" Perception of traditional food product in six European regions using free word association 21 225-233 Doi; 10.1016/j.foodequal.200.06.003

[11] Calderon, J., Gonzales, E. 1993. Methods of Research and Thesis Writing Collecting Data in Mixed Methods Research-06-Creswell (Designing)- 45025.pxd 5/16/2006 http://www.sagepub.com/upmdata/10983 Chapter 6.pdf

[12] Fernadez, D.G., Edilberto N. 2013. Alegre Sarap Es-says on Philippine Food Duke University word press.

[13] Enriquez, M. 1993. Author Kasaysayan ng kaluto ng Bayan

[14] Erickson, B.H. 1996. Culture, Class and Connections. American Journal of Sociology, 102 (1), 217-251.

[15] Experiment-Resources.com. 2009. Quantitative and Qualitative Research. Retrieved 23 Aug.2012 from Experiment Re-sources 